\title{
Manifesting carriers of X-linked myotubular myopathy
}

\author{
Genetic modifiers modulating the phenotype
}

\author{
Lucas Santos Souza, MSc, Camila Freitas Almeida, PhD, Guilherme Lopes Yamamoto, MD, PhD, \\ Rita de Cássia Mingroni Pavanello, MD, Juliana Gurgel-Giannetti, MD, PhD, Silvia Souza da Costa, PhD, \\ Isabela Pessa Anequini, Bsc, Silvana Amanda do Carmo, Bsc, Jaqueline Yu Ting Wang, MSc, \\ Marília de Oliveira Scliar, PhD, Erick C. Castelli, PhD, Paulo Alberto Otto, MD, PhD, Edmar Zanoteli, MD, PhD, \\ and Mariz Vainzof, PhD
}

Neurol Genet 2020;6:e513. doi:10.1212/NXG.0000000000000513

\section{Abstract \\ Objective}

To analyze the modulation of the phenotype in manifesting carriers of recessive $\mathrm{X}$-linked myotubular myopathy (XLMTM), searching for possible genetic modifiers.

\section{Methods}

Twelve Brazilian families with XLMTM were molecularly and clinically evaluated. In 2 families, 4 of 6 and 2 of 5 manifesting female carriers were identified. These females were studied for X chromosome inactivation. In addition, whole-exome sequencing was performed, looking for possible modifier variants. We also determined the penetrance rate among carriers of the mutations responsible for the condition.

\section{Results}

Mutations in the MTM1 gene were identified in all index patients from the 12 families, being 4 of them novel. In the heterozygotes, $X$ chromosome inactivation was random in 3 of 4 informative manifesting carriers. The disease penetrance rate was estimated to be $30 \%$, compatible with incomplete penetrance. Exome comparative analyses identified variants within a segment of $4.2 \mathrm{Mb}$ on chromosome 19, containing the killer cell immunoglobulin-like receptor cluster of genes that were present in all nonmanifesting carriers and absent in all manifesting carriers. We hypothesized that these killer cell immunoglobulin-like receptor variants may modulate the phenotype, acting as a protective factor in the nonmanifesting carriers.

\section{Conclusions}

Affected XLMTM female carriers have been described with a surprisingly high frequency for a recessive $\mathrm{X}$-linked disease, raising the question about the pattern of inheritance or the role of modifier factors acting on the disease phenotype. We demonstrated the possible existence of genetic mechanisms and variants accountable for the clinical manifestation in these women, which can become future targets for therapies.

\author{
Correspondence \\ Dr. Vainzof \\ mvainzof@usp.br
}




\section{Glossary}

CMs = congenital myopathies; $\mathbf{C N M}=$ centronuclear myopathy; DMD = Duchenne muscular dystrophy; FVC = forced vital capacity; KIR = killer cell immunoglobulin-like receptor; $\mathbf{M C}=$ manifesting carrier; $\mathbf{M M T}=$ manual muscle testing; $\mathrm{NMC}=$ nonmanifesting carrier; XCI = X chromosome inactivation; XLMTM = X-linked myotubular myopathy.

Congenital myopathies (CMs) are muscle disorders present at birth or early infancy. Among the CMs, centronuclear myopathies (CNMs) are characterized by the presence of centrally located nuclei in muscle fibers. Three inherited forms of CNMs are recognized: autosomal dominant, autosomal recessive, and $\mathrm{X}$-linked recessive forms, caused by mutations in DNM2 (19p13.2), ${ }^{1}$ BIN1 (2q14.3), ${ }^{2}$ and MTM1(Xq2.8) ${ }^{3}$ genes, respectively. X-linked myotubular myopathy is the most severe form, ${ }^{3,4}$ with an estimated frequency of 1/50,000 living births. The classical phenotype includes severe hypotonia, global muscle weakness, respiratory insufficiency, difficulty to feed, ptosis, ophthalmoplegia, inguinal hernia, and cryptorchidism in the neonatal period. ${ }^{3,4}$

Considering that X-linked myotubular myopathy (XLMTM) is classified as a recessive $\mathrm{X}$-linked disorder, typically heterozygous females are expected to be asymptomatic. However, recent reports have identified several XLMTM heterozygous females, with a wide spectrum of clinical phenotype. ${ }^{5}$

This high frequency of XLMTM manifesting women is intriguing, especially if compared with other recessive X-linked disorders. Many attempts to explain this question have been made, including the study of skewed X inactivation in XLMTM. ${ }^{6,7}$ However, unlike in several other X-linked diseases, ${ }^{8}$ the search for modifier variants in XLMTM has not been performed.

Here, we present 2 Brazilian families with manifesting (MC) and nonmanifesting carriers (NMC), and the genetic factors that may explain these phenotypic differences.

\section{Methods}

\section{Standard protocol approvals, registrations, and patient consents}

The present study is in accordance and was approved by the Ethic Committee of the Biosciences Institute of the University of São Paulo, and the DNA samples are deposited in the biobank repository of the Human Genome and Stem Cell Research Center of IB-USP. All patients participating in this study signed an appropriated informed consent.

\section{Patient selection}

We evaluated 12 families at the Neuromuscular Disease Ambulatory of the Human Genome and Stem Cell Research Center from the Institute of Biosciences of the University of São Paulo. The patient selection criteria included clinical and histopathologic features of XLMTM myopathy. Muscle biopsy findings, such as small fibers with central nuclei, predominance of type I fibers, concentration of myofibrils in the periphery of the fiber as they are absent in the central area, and accumulations of mitochondria and glycogen in the central region, were suggestive of XLMTM.

A team of neurologists and physiotherapists performed clinical evaluation and estimation of muscle strength in upper and lower members, shoulder and pelvic girdles, using the Manual Muscle Testing (MMT) in which muscle strength is measured in accordance with the Medical Research Council (MRC) score system. ${ }^{9}$ Ventilatory function was assessed using spirometry (forced vital capacity [FVC], in the supine and sitting position) and cough efficacy, according to the Brazilian Society of Pneumology and Tisiology. ${ }^{10}$

\section{Molecular diagnosis}

\section{Next-generation sequencing panel}

To perform molecular analysis, we used a custom panel of 500 genes, including MTM1 and 88 other genes associated with neuromuscular diseases. We used the Nextera Rapid Capture Custom Enrichment Kit (Illumina, San Diego, CA) for library preparation and capture and the HiSeq2500 equipment (Illumina, San Diego, CA) for sequencing. The raw data (fastq files) was aligned against the GRCh37/hg19 human genome reference using BWA-MEM, with a postprocessing step using Picard Tools 1.81 to convert sam files to bam files and to mark PCR duplicates. We called genotypes using the Genome Analysis Toolkit (GATK) UnifiedGenotyper, version 3.7, following the GATK best practices. All variants were annotated using ANNOVAR.

\section{Whole-exome sequencing-Search for modifier genes and variants}

We performed whole-exome sequencing of 9 heterozygous women for MTM1 mutation from 2 families, including 5 manifesting and 4 asymptomatic carriers to identify possible variants that may modify the phenotype. For that, we used the SureSelectQXT V6 Reagent Kit (Agilent, Santa Clara, CA) for library preparation and capture and the HiSeq2500 equipment (Illumina) for sequencing. We applied the same pipeline used for panels, as described above, for sequencing reads alignment, variant calling, and annotation.

At first glance, we detected variants within the killer cell immunoglobulin-like receptor (KIR) complex that are differently distributed between symptomatic and asymptomatic women. Because the KIR complex has a repetitive and polymorphic nature, it is expected some misalignment and genotyping errors leading to false associations. To circumvent 
Table 1 List of MTM1 mutations identified in the 12 families presenting X-linked myotubular myopathy

\begin{tabular}{|c|c|c|c|c|c|}
\hline Family & Exon & Mutation & Protein & No. of identified carriers & Report \\
\hline 1 & 3 & c. $109 \mathrm{C}>\mathrm{T}$ & p.(Arg37Ter) & 6 & Laporte et al. ${ }^{24}$ \\
\hline 2 & 4 & c.139_142delAAAG & p.(Glu48LeufsTer24) & 1 & de Gouyon et al. ${ }^{23}$ \\
\hline 3 & 9 & c.706A>T & p.(Lys236Ter) & 0 (de novo) & Hedberg et al. ${ }^{25}$ \\
\hline 4 & 10 & c. $1010 \mathrm{G}>\mathrm{A}$ & p.(Trp337Ter) & 0 (de novo) & Novel \\
\hline 5 & 11 & c. $1181 \mathrm{~A}>\mathrm{G}$ & p.(Asp394Gly) & 3 & Novel \\
\hline 6 & 12 & c. $1262 \mathrm{G}>\mathrm{A}$ & p.(Arg421Gln) & - & de Gouyon et al. ${ }^{23}$ \\
\hline 7 & 13 & c. $1354+1 \mathrm{G}>\mathrm{C}$ & $?$ & - & Tanner et al. ${ }^{26}$ \\
\hline 8 & 13 & c. $1354+1 G>C$ & $?$ & - & Tanner et al. ${ }^{26}$ \\
\hline 9 & 13 & c.1465_1465delC & p.(Gln489ArgfsTer13) & - & Novel \\
\hline 10 & 13 & c. $1467+1 \mathrm{G}>\mathrm{A}$ & $?$ & 1 & Herman et al. ${ }^{22}$ \\
\hline 11 & 14 & c. $1528 \mathrm{~A}>\mathrm{T}$ & p.(Lys510Ter) & - & Novel \\
\hline 12 & 14 & c. $1644+1 \mathrm{G}>\mathrm{A}$ & $?$ & 5 & Biancalana et al. ${ }^{5}$ \\
\hline
\end{tabular}

Reference sequence NM_00025.2.

this issue, we further performed another call of genotypes using a different approach. We used an adapted version of the hla-mapper software ${ }^{11}$ with databases of known KIR sequences, optimizing the reads mapping in the KIR complex. This version is focused on the KIR framework genes, KIR2DL4, KIR3DL3, KIR3DL2, and other important receptors such as LILRB1 and LILRB2, and also the HLA class I genes. After mapping optimization, we used GATK HaplotypeCaller (GVCF mode, version 4.1.1) to call genotypes, joining samples' GVCF files using CombinedGVCF and finally calling the variants using GenotypeGVCF. Following the variant calling process, we performed a variant refinement and filtration step using vcfx checkpl, vcfx checkad, and vcfx evidence (castelli-lab.net/apps/vcfx), as described elsewhere. ${ }^{12}$ We annotated variants using ANNOVAR.

\section{Sanger sequencing-Mutation validation and segregation analysis}

We used Sanger sequencing to validate pathogenic mutations and to evaluate all members of the families, allowing a segregation study within the families. The mutated segments were amplified by PCRs using Platinum Taq DNA Polymerase (Invitrogen, Carlsbad, CA) and specific primers for each segment. Amplicons were purified using ExoSAP-IT (Applied Biosystems, Foster City, $\mathrm{CA}$ ) and sequenced using the BigDye Terminator v3.1 (Applied Biosystems) kit and a 3730 DNA Analyzer (Applied Biosystems) sequencer. We used Chromas (Technelysium, Australia) to evaluate chromatograms.

\section{$X$ chromosome inactivation analysis}

We analyzed the X chromosome inactivation (XCI) pattern in 9 MTM1 heterozygous women using a protocol described by Allen et al., ${ }^{13}$ following the principle of digestion of the polymorphic and CAG-rich regions of the human androgen receptor gene. We used HpaII enzyme for digestion followed by sequencing using the 3730 DNA Analyzer (Applied Biosystems) sequencer. Next, we calculated the proportion of skewed XCI using the formula proposed by Bittel et al. ${ }^{14}$

\section{Penetrance rate estimation}

To estimate the penetrance rate $\mathrm{K}$ of carriers of MTM1 mutations, we used the genealogical data from 10 different families with affected individuals, 2 of them studied by us and described in the present article and 8 families from the literature. ${ }^{6,15-21}$ The 8 families culled from the literature were selected once clinical description was clear and concordant with described XLMTM manifesting carriers from scientific and medical literature (muscle weakness and body asymmetry), plus whether pedigrees or information of kinship were present.

Penetrance rate estimation was achieved by using standardized methods, fully detailed in supplementary material 1 , lww. com/NXG/A314, to this article.

\section{Data availability}

The data sets generated during and/or analyzed during the current study are available on request.

\section{Results}

\section{Case report and MTM1 mutations}

We identified 11 different MTM1 mutations in the index patients from 12 families evaluated at our center (table 1). Five variants are nonsense mutations, 1 is frameshift, 2 are missense, and 3 are splicing modification mutations. One mutation, c.1354+1G>C, was recurrent in 2 unrelated 


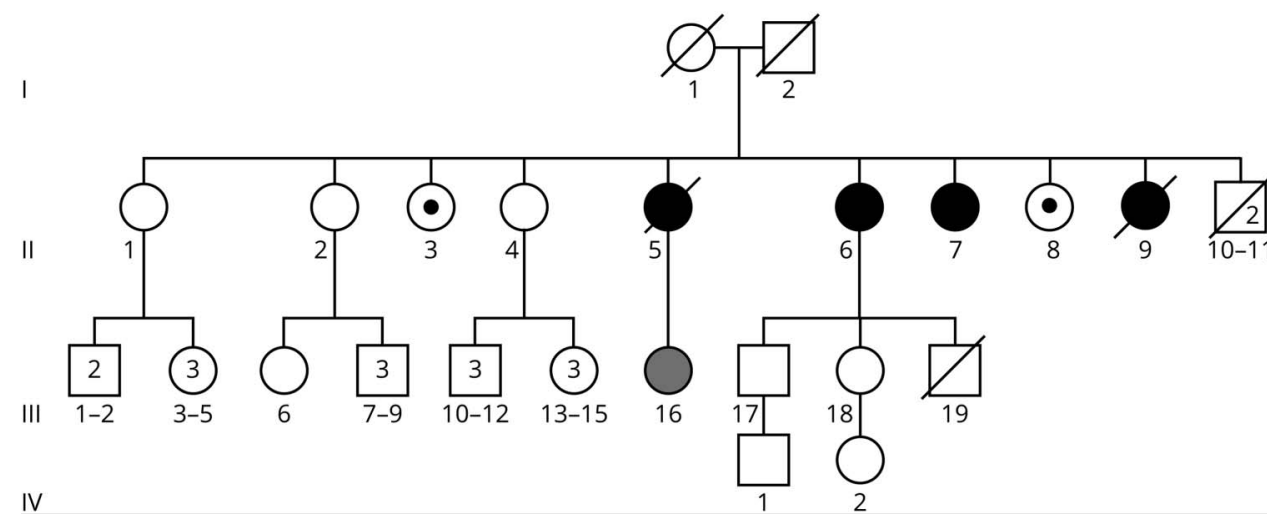

We identified 4 affected females (black filled circles), 2 nonmanifesting carriers (indicated by a black dot inside the circle), and 1 affected female with a mild phenotype (indicated by a gray filled circle). Deceased individuals are indicated by an oblique line.

families. Four mutations are novel, whereas 7 were previously described as pathogenic. ${ }^{5,22-26}$

We were able to perform mutation screening in female relatives from 7 families, and we identified carriers in 5 of them. Clinical examination was possible in 2 of these families, and we identified 4 (of 6) (family 1) and 2 (of 5) (family 12) female carriers presenting some level of clinical manifestation.

\section{Heterozygous women and symptomatic carriers}

In family 1,5 of 8 sisters are heterozygous for c.109C $>\mathrm{T}$ MTM1 mutation, and 4 of them manifest a phenotype (figure 1). This nonsense mutation leads to a premature stop codon and was previously described as pathogenic. ${ }^{24}$

The c.109C $>$ T mutation was also screened in individuals II.1-8 and III.16, and it is present in II.3, II.8, and III.16. Patients II.5-7 and III.16 were considered clinically affected, whereas carriers II. 3 and II. 8 showed no weakness or any clinical symptom.

\section{Description of the manifesting carriers}

\section{II.5}

The patient died at age 64 years. Onset of symptoms was at 49 years and was characterized by weakness in the upper and lower limbs. In the last clinical evaluation at age 60 years, the patient walked with the help of a walker apparatus and had no ability to get up from the chair without support. The MMT showed an important reduction of the muscle strength predominant in proximal muscles of upper (grade 4) and lower (grade 3) limbs. In addition, the patient had clinical manifestations of ventilatory insufficiency (dyspnea and poor efficacy cough) and severe restrictive ventilatory disorder (FVC of the $41 \%$ ), with a noninvasive nightly ventilatory support.

\section{II.6}

This patient was aged 63 years. The symptoms started at 48 years and were characterized by progressive weakness in the upper and lower limbs. At the last evaluation, she was able to get up from chairs and climb stairs without support but presented some difficult to get up off the floor and run. Neurologic examination identified a predominant weakness of proximal muscles of the upper (MMT grade 4) and lower (MMT grade 4-) limbs. In addition, abdominal weakness, left biceps and triceps atrophy, slightly enlarged thighs and calves, and thoracic kyphoscoliosis were noted.

\section{II.7}

This patient was aged 59 years. Muscle weakness in the upper and lower limbs was first noticed at 43 years. At the last evaluation, she could not rise from the floor without help, but was able to walk, get up from chairs, and climb stairs. She had previous vertebral fracture due to a fall that was treated with a thoracic cast. Neurologic examination identified a predominant weakness of proximal muscles of the upper (MMT grade 4) and lower (MMT grade 4-) limbs. In addition, she had clinical ineffective cough and a severe restrictive ventilatory disorder (FVC of the 36\%) with a nightly noninvasive ventilatory support. Other clinical findings were calf hypertrophy, thigh, biceps, and brachial triceps atrophy, and weakness of cervical, abdominal, and paravertebral muscles. Limb muscles from the right side appeared to be more affected than the left side.

\section{III.16}

This patient was aged 30 years and had a mild clinical involvement. She was able to get up from the chair and the floor with minimal difficulty and no support. Neurologic examination showed a predominant weakness of proximal muscles of the upper (MMT grade 4+) and lower (MMT grade 4) limbs. She underwent bariatric surgery at age 26 years and was treated for pituitary adenoma. She mentioned the occurrence of cramps and muscle fatigue when walking long distances. She had calf enlargement and mild global hypotonia, with no facial involvement.

In family 12 , the c.1644+1G $>$ A mutation at intron 14 was previously identified in the affected male patient at another 


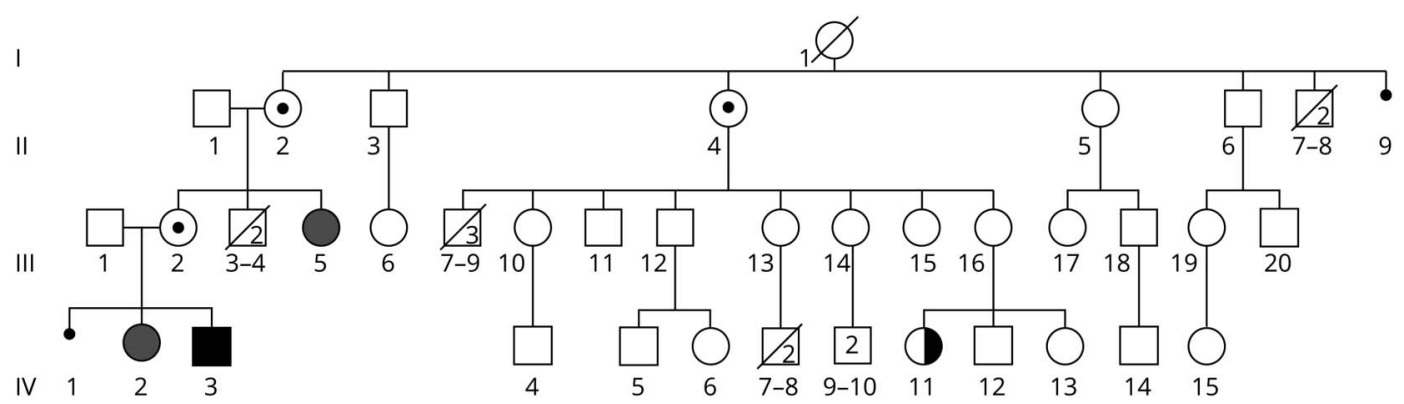

We identified 1 affected young boy (black filled square) and the 5 identified carriers from this family: 2 manifesting carriers (indicated by gray filled circles) and 3 nonmanifesting carriers (indicated by a black dot inside the circle). Deceased individuals are indicated by an oblique line.

diagnostic center. The screening for this mutation by Sanger sequencing was performed in this study, and we identified the mutation in the mother (III.2), sister (IV.2), aunt (III.5), maternal grandmother (II.2), and maternal aunt (II.4) of the proband (IV.3). Evaluation of the carriers identified affected phenotype in the sister (IV.2) and the aunt (III.5) (figure 2).

\section{III.5}

This patient was aged 33 years and had mild clinical involvement. She was able to get up from the floor and from the chair and climb stairs without support and showed the Trendelenburg sign on her left hip (hip abductor weakness) during walking. Neurologic examination showed a predominant weakness of proximal muscles of the upper (MMT grade 5-) and lower (MMT grade 4+) limbs. The patient had no symptoms or signals of respiratory involvement, and the FVC was normal. The patient did not complain about muscle fatigue and falls.

\section{IV.2}

This patient was aged 9 years and had no complain about weakness or motor function limitation. She could rise from the floor, climb stairs, and walk without support. Neurologic examination showed a mild muscle weakness in the proximal portions of the upper and lower limbs (MMT grade 5-). In addition, clinical examination showed a triangular facial aspect, hypertelorism, and slight palpebral ptosis, with no facial weakness. No osteoskeletal deformities were noticed. A mild distal atrophy in the distal region of the left thigh was observed. The patient did not complain about pain and muscle fatigue, stumbles, and falls. The patient had no symptoms or signals of respiratory involvement, and the FVC was normal.

\section{$\mathrm{X}$ chromosome inactivation analysis}

We performed XCI analysis in 5 heterozygous women from family 1 (II.3, II.5, II.6, II.7, and II.8) and in 4 women from family 12 (II.2, III.2, III.5, and IV.2) (table 2). There was no $\mathrm{XCI}$ deviation in 4 of the women in whom the test was informative (II.3, II.6, II.7, and II.8), 2 of them (II.6 and II.7) manifesting the phenotype. Among the 4 women studied in family 12, in 3 (II.2, III.2, and IV.2), the test was informative, and we observed a random inactivation pattern of the $\mathrm{X}$ chromosome.

\section{Penetrance rate $(\mathrm{K})$ estimation}

The estimated $\mathrm{K}$ value was 0.298 , with an exact $95 \%$ credible (or confidence) interval of 0.192-0.423. As already mentioned, details on the model and the methods we used to obtain the above value can be found in the supplementary material, lww.com/NXG/A314.

\section{Searching for modifier genes}

For the exome comparisons between the 4 NMCs and the 5 MCs (figures 1 and 2), we based our first survey on the genotypes inferred by the GATK Unified Genotyper algorithm and a filtering step to evaluate 2 main hypotheses: (1) the presence of inducing variants only in the MC and (2) the presence of

Table 2 X chromosome inactivation study in the 2 MTM1 families

\begin{tabular}{lll}
\hline & Phenotype & X chromosome inactivation \\
\hline Family 1 & & \\
\hline II.3 & NMC & Random \\
\hline II.5 & MC & Noninformative \\
\hline II.7 & MC & Random \\
\hline II.8 & MC & Random \\
\hline Family 12 & NMC & Random \\
\hline II.2 & & \\
\hline III.2 & NMC & Random \\
\hline III.5 & MC & Random \\
\hline IV.2 & MC & Noninformative \\
\hline
\end{tabular}

Abbreviations: Phenotype: $\mathrm{MC}=$ manifesting carrier; $\mathrm{NMC}=$ Nonmanifesting carrier. 
protective variants in the NMC only. For the first hypothesis, we obtained 32 variants, whereas for the second one, we obtained 72 variants. Intriguingly, most of the protective variants are located within a 4.2-Mb block on chromosome 19. This region contains, among others, many genes that belong to the KIR cluster. After applying the mapping optimization using hlamapper followed by vcfx checkpl/checkad/evidence, we confirmed 3 variants that passed all the filters and that are present in heterozygosis in all nonaffected carriers and absent in the affected ones. Two of these variants mark the presence of the allele KIR2DL4*00501 (rs604076 and rs652671), and the third is related to the allele KIR3DL2*007 (rs654686) (table 3). These variants present a high linkage disequilibrium and are related to a common European KIR haplotype, which also includes copies of the alleles KIR3DS1*01301, KIR2DL5A ${ }^{*} 0010101$, KIR2DS5*00201, and KIR2DS1 ${ }^{*} 00201{ }^{27}$ We called this haplotype as a protective haplotype, assuming that it might be preventing the nonaffected carriers from manifesting any symptoms.

Further exome analysis of additional 180 individuals from our routine diagnostic service allowed us to identify a proportion of $27 \%$ of Brazilian individuals carrying the protective variants.

We also screened other CNM-related genes such as DNM2 and BIN1 searching for variants that fitted our 2 hypotheses, but there were no relevant variants segregating with the phenotype in neither of these genes.

\section{Discussion}

XLMTM myopathy due to mutations in the MTM1 gene has been classified as a recessive $\mathrm{X}$-linked disease, with a very severe phenotype involving muscle weakness, affecting mainly boys in the neonatal period. However, affected females carrying mutations in this gene have been described, but with a surprisingly higher frequency than expected for an X-linked recessive disease. ${ }^{5-7,16-21,28}$ These new findings have risen the question whether the inheritance pattern associated with this gene is indeed recessive or whether modifier factors are acting in the manifestation of the phenotype.

All the patients studied here were under investigation in our center in the last 20 years, and most of them presented at that time the classical clinical course of XLMTM. Among the 7 families in which the study of female relatives was possible, we detected mutation carriers in mothers from 5 families, which is compatible with the expected proportion of $2 / 3$ inherited cases of lethal mutations in the $\mathrm{X}$ chromosome. ${ }^{29}$

For the majority of recessive X-linked diseases, heterozygous women do not manifest the disease because of the normal allele expression that is expected to be sufficient to maintain the usual gene function. One important example is the low frequency of manifesting carriers in Duchenne muscular dystrophy (DMD) and Becker muscular dystrophy. DMD has a much higher 
incidence than XLMTM, 1/3,000 male births. Nevertheless, several studies have shown a frequency of $2.5 \%-7.8 \%$ female carriers with some clinical manifestations. ${ }^{30}$ Conversely, XLMTM, with a frequency of $1 / 50,000$ living births, has shown a much higher number of manifesting carriers worldwide, reaching, in this study, the proportion of $\sim 50 \%$. This highlights the importance of better studying the factors involved in phenotype manifestation in this disease.

The main proposed cause to justify the phenotypic manifestation in carriers of myotubular myopathy has been a skewed inactivation of the $\mathrm{X}$ chromosome. This mechanism is also considered to be responsible for the clinical picture in dystrophinopathies and in other X-linked diseases. However, studies of skewed $\mathrm{X}$ inactivation in dystrophinopathies are controversial, once it is defended by some authors, ${ }^{31}$ and excluded by others. ${ }^{32}$ One of several explanations for this disagreement is that XCI analysis performed on blood lymphocytes does not reflect the actual state of inactivation present in the whole organism or the pattern in muscle cells. Besides, analysis of XCI in 1 muscle should not be representative for all muscles because women are naturally a mosaic for XCI. Anyhow, there are studies that show a good concordance between the inactivation pattern between muscle cells and blood lymphocytes because they have a common embryonic origin. ${ }^{33,34}$

Of the 25 cases of XLMTM manifesting carriers published so far by other groups, 17 were informative for the XCI pattern. XCI was considered random in 11 and skewed in 6 cases. In the heterozygotes identified in this study, there was no correlation between the inactivation pattern and the phenotypes, supporting that the inactivation pattern does not explain the phenotype.

The identification of heterozygous women manifesting phenotypes linked to the X-chromosome has raised doubts in the literature on the classification of the inheritance pattern as recessive or dominant. The high degree of variability in the penetrance value of many X-linked conditions is hardly explained under traditional classification criteria of monogenic diseases. Dobyns ${ }^{35}$ state that the modern rules of $\mathrm{X}$-linked inheritance classification are not able to explain the high number of heterozygous females showing X-recessive disorders' phenotypes. They reviewed 32 diseases related to the $\mathrm{X}$ chromosome, estimating more broadly the penetrance rate in women, demonstrating that a range of penetrance values can be estimated. Thus, the classification rules of inheritance models linked to the $\mathrm{X}$ chromosome should be revisited.

Regarding myotubular myopathy, our findings are in agreement with what was proposed by Dobyns and are compatible with an incomplete penetrance pattern, supporting the high frequency of women affected by XLMTM.

The clinical manifestations of XLMTM in heterozygous women may be influenced by the interaction between different secondary genes and the primary molecular defect, modulating the phenotypic expression. This hypothesis is plausible considering other diseases in which the same genotype is associated with phenotypic variability ${ }^{36}$ or diverse phenotypes. There are diseases in which the presence of genomic variants has the effect of altering its expression, as already reported in DMD. ${ }^{8,37}$ The identification of these variants may explain the clinical picture observed among the women of both families presented here. After comparing MC and NMC, we identified variants at the KIR cluster located at the leukocyte receptor complex in19q13.4 chromosome. All healthy women were heterozygous for at least 3 variants (table 3) from 2 KIR genes, KIR2DL4 located in the center of the KIR cluster and KIR3DL2 (the last telomeric gene of the cluster).

The KIR genes are ordered in a tandem fashion that spans over $150 \mathrm{~kb}$. Up to today, $15 \mathrm{KIR}$ genes and 2 pseudogenes have been identified, ${ }^{38}$ composing a family of homologous, but highly polymorphic genes. In addition, only 3 KIR genes are present in every individual and are considered framework genes, KIR3DL3, KIR2DL4, and KIR3DL2, whereas other KIR genes may be present or not depending on the individual KIR haplotype.

The variants listed in table 3 mark the presence of 2 specific alleles, named KIR2DL4*00501 and KIR3DL2*007, both in high linkage disequilibrium, commonly detected among Europeans. These KIR alleles usually mark a KIR haplotype that also contains KIR3DS1*01301, KIR2DL5A*0010101, KIR2DS5 ${ }^{*} 00201$, and KIR2DS1 ${ }^{*} 00201 .{ }^{27}$ Thus, these variants are defining a specific KIR haplotype.

So far, there are no data regarding the general frequency of KIR haplotypes in the Brazilian population. However, the frequency of the protective KIR haplotype in our large cohort of 180 unrelated whole exomes is compatible with a more frequent polymorphism acting as a possible modifier, and it is also compatible with the penetrance rate estimated for these females.

KIR genes have important roles in the modulation of the immune response against pathogens and autoimmune disorders, such as HIV/AIDS. ${ }^{39}$ Thus, the association of KIRs and diseases has been largely studied, and specific database has been developed for this purpose (KIR and Disease Database).

To date, it is unknown whether there is any relation between the KIR cluster and the modulation of neuromuscular disorders. Studies have shown that KIR genes interact with CD56 (N-CAM) in NK lymphocytes. ${ }^{40}$ CD56 is also present on the surface of myoblasts and highly expressed during muscle regeneration after injury. CD56 may act as a modulator of the interaction between satellite cells and myoblasts to the extracellular matrix and may participate in the secondary response mechanisms that lead to repair and remodeling. ${ }^{41}$ Hence, an association between the KIR genes and the skeletal 
muscle might be possible through the KIR-CD56 interaction. It will be a challenge to demonstrate how a specific haplotype of KIR genes could modulate the myotubular myopathy phenotype, protecting carriers of the MTM1 mutations from presenting a phenotype, but we believe that further efforts should be made to answer this question, primarily by increasing the number of affected women and families to try to replicate the findings. We hope that deepening this study can eventually open a new field for therapeutic approaches.

\section{Acknowledgment}

The authors thank the scientific and technical support of the team from the Human Genome and Stem Cell Research Center of the University of São Paulo, São Paulo, Brazil.

\section{Study funding}

This work was supported by Conselho Nacional de Desenvolvimento Cientifico e Tecnológico ( $\mathrm{CNPq}$ projetos 456522/2014-0), Fundação de Amparo à Pesquisa do Estado de São Paulo-Centro de Pesquisa, Inovação e Difusão (FAPESP-CEPID projeto 2013/08028-1), Financiadora de Estudos e Projetos (FINEP-projeto 01.08.0579.00), and Coordenação de Aperfeiçoamento de Pessoal de Nível Superior (CAPES).

\section{Disclosure}

The authors report no disclosures relevant to the manuscript. Go to Neurology.org/NG for full disclosure.

\section{Publication history}

Received by Neurology: Genetics February 21, 2020. Accepted in final form July 16, 2020.

Appendix Authors

\begin{tabular}{|c|c|c|}
\hline Name & Location & Contribution \\
\hline $\begin{array}{l}\text { Lucas Santos } \\
\text { Souza, MSc }\end{array}$ & $\begin{array}{l}\text { Human Genome and Stem } \\
\text { Cell Research Center, } \\
\text { University of São Paulo, } \\
\text { São Paulo, Brazil }\end{array}$ & $\begin{array}{l}\text { Conceived, designed, and } \\
\text { performed the } \\
\text { experiments and } \\
\text { elaborated, wrote, and } \\
\text { reviewed the manuscript }\end{array}$ \\
\hline $\begin{array}{l}\text { Camila } \\
\text { Freitas } \\
\text { Almeida, PhD }\end{array}$ & $\begin{array}{l}\text { Human Genome and Stem } \\
\text { Cell Research Center, } \\
\text { University of São Paulo, } \\
\text { São Paulo, Brazil }\end{array}$ & $\begin{array}{l}\text { Conceived, designed, and } \\
\text { performed the } \\
\text { experiments and } \\
\text { elaborated, wrote, and } \\
\text { reviewed the } \\
\text { manuscript }\end{array}$ \\
\hline $\begin{array}{l}\text { Guilherme } \\
\text { Lopes } \\
\text { Yamamoto, } \\
\text { MD, PhD }\end{array}$ & $\begin{array}{l}\text { Human Genome and Stem } \\
\text { Cell Research Center, } \\
\text { University of São Paulo, } \\
\text { São Paulo, Brazil }\end{array}$ & $\begin{array}{l}\text { Contributed with genetics } \\
\text { and genomics } \\
\text { bioinformatics analyses } \\
\text { and manuscript revision }\end{array}$ \\
\hline $\begin{array}{l}\text { Rita de Cássia } \\
\text { Mingroni } \\
\text { Pavanello, } \\
\text { MD }\end{array}$ & $\begin{array}{l}\text { Human Genome and Stem } \\
\text { Cell Research Center, } \\
\text { University of São Paulo, } \\
\text { São Paulo, Brazil }\end{array}$ & $\begin{array}{l}\text { Performed medical and/ } \\
\text { or physical evaluation of } \\
\text { the patients }\end{array}$ \\
\hline $\begin{array}{l}\text { Juliana } \\
\text { Gurgel- } \\
\text { Giannetti, } \\
\text { MD, PhD }\end{array}$ & $\begin{array}{l}\text { Department of Pediatrics, } \\
\text { Medical School of Federal } \\
\text { University of Minas Gerais, } \\
\text { Belo Horizonte, MG, Brazil }\end{array}$ & $\begin{array}{l}\text { Performed medical and/ } \\
\text { or physical evaluation of } \\
\text { the patients and } \\
\text { contributed with } \\
\text { manuscript revision }\end{array}$ \\
\hline
\end{tabular}

Appendix (continued)

\begin{tabular}{lll}
\hline Name & Location & Contribution \\
\hline $\begin{array}{l}\text { Silvia Souza } \\
\text { da Costa, PhD }\end{array}$ & $\begin{array}{l}\text { Human Genome and Stem } \\
\text { Cell Research Center, } \\
\text { University of São Paulo, } \\
\end{array}$ & $\begin{array}{l}\text { Performed the } \\
\text { experiments }\end{array}$ \\
& São Paulo, Brazil &
\end{tabular}

Isabela Pessa Human Genome and Stem Performed medical and/

Anequini, Bsc Cell Research Center, or physical evaluation of University of São Paulo, the patients São Paulo, Brazil

\begin{tabular}{lll}
\hline $\begin{array}{l}\text { Silvana } \\
\text { Amanda do } \\
\text { Carmo, Bsc }\end{array}$ & $\begin{array}{l}\text { Human Genome and Stem } \\
\text { Cell Research Center, } \\
\text { University of São Paulo, } \\
\text { São Paulo, Brazil }\end{array}$ & $\begin{array}{l}\text { Performed medical and/ } \\
\text { or physical evaluation of } \\
\text { the patients }\end{array}$ \\
\hline $\begin{array}{l}\text { Jaqueline Yu } \\
\text { Ting Wang, } \\
\text { MSc }\end{array}$ & $\begin{array}{l}\text { Human Genome and Stem } \\
\text { Cell Research Center, } \\
\text { University of São Paulo, } \\
\text { São Paulo, Brazil }\end{array}$ & $\begin{array}{l}\text { Contributed with genetics } \\
\text { and genomics } \\
\text { bioinformatics analyses } \\
\text { and manuscript revision }\end{array}$ \\
\hline $\begin{array}{l}\text { Marília de } \\
\text { Oliveira } \\
\text { Scliar, PhD }\end{array}$ & $\begin{array}{l}\text { Human Genome and Stem } \\
\text { Cell Research Center, } \\
\text { University of São Paulo, }\end{array}$ & $\begin{array}{l}\text { Contributed with genetics } \\
\text { and genomics } \\
\text { bioinformatics analyses } \\
\text { and manuscript } \\
\text { revision }\end{array}$ \\
\hline
\end{tabular}

Erick C. São Paulo State University Contributed with genetics

$\begin{array}{lll}\text { Castelli, PhD } & \text { São Paulo State University } & \text { Contributed with genetics } \\ & \text { (UNESP), Pathology } & \text { and genomics } \\ & \text { Department, School of } & \text { bioinformatics analyses } \\ & \text { Medicine, Botucatu, State } & \text { and manuscript revision }\end{array}$
of São Paulo, Brazil

\begin{tabular}{lll}
\hline $\begin{array}{l}\text { Paulo Alberto } \\
\text { Otto, MD, } \\
\text { PhD }\end{array}$ & $\begin{array}{l}\text { Human Genome and Stem } \\
\text { Cell Research Center, } \\
\text { University of São Paulo, } \\
\text { São Paulo, Brazil }\end{array}$ & $\begin{array}{l}\text { Contributed with genetics } \\
\text { and genomics } \\
\text { bioinformatics analyses } \\
\text { and manuscript revision }\end{array}$ \\
\hline $\begin{array}{l}\text { Edmar } \\
\text { Zanoteli, MD, } \\
\text { PhD }\end{array}$ & $\begin{array}{l}\text { Department of Neurology, } \\
\text { Medical School of the } \\
\text { University of Sao Paulo, } \\
\text { São Paulo, Brazil }\end{array}$ & $\begin{array}{l}\text { Performed medical and/ } \\
\text { or physical evaluation of } \\
\text { the patients }\end{array}$ \\
\hline $\begin{array}{l}\text { Mariz } \\
\text { Vainzof, PhD }\end{array}$ & $\begin{array}{l}\text { Human Genome and Stem Research Center, } \\
\text { Cell Rniversity of São Paulo, }\end{array}$ & $\begin{array}{l}\text { Conceived, designed, and } \\
\text { performed the } \\
\text { experiments and } \\
\text { elaborated, wrote, and } \\
\text { reviewed the manuscript }\end{array}$ \\
& $\begin{array}{l}\text { São Paulo, Brazil } \\
\end{array}$
\end{tabular}

\section{References}

1. Bitoun M, Maugenre S, Jeannet PY, et al. Mutations in dynamin 2 cause dominant centronuclear myopathy. Nat Genet 2005;37:1207-1209.

2. Nicot AS, Toussaint A, Tosch V, et al. Mutations in amphiphysin 2 (BIN1) disrupt interaction with dynamin 2 and cause autosomal recessive centronuclear myopathy. Nat Genet 2007;39:1134-1139.

3. Laporte J, Biancalana V, Tanner SM, et al. MTM1 mutations in X-linked myotubular myopathy. Hum Mutat 2000;15:393-409.

4. Biancalana V, Caron O, Gallati S, et al. Characterisation of mutations in 77 patients with $\mathrm{X}$-linked myotubular myopathy, including a family with a very mild phenotype. Hum Genet 2003;112:135-142.

5. Biancalana V, Scheidecker S, Miguet M, et al. Affected female carriers of MTM1 mutations display a wide spectrum of clinical and pathological involvement: delineating diagnostic clues. Acta Neuropathol 2017;134:889-904.

6. Tanner SM, ØRstavik KH, Kristiansen M, et al. Skewed X-inactivation in a manifesting carrier of X-linked myotubular myopathy and in her non-manifesting carrier mother. Hum Genet 1999;104:249-253.

7. Kristiansen M, Knudsen GP, Tanner SM, et al. X-inactivation patterns in carriers of X-linked myotubular myopathy. Neuromuscul Disord 2003;13:468-471.

8. Vieira NM, Elvers I, Alexander MS, et al. Jagged 1 rescues the Duchenne muscular Dystrophy phenotype. Cell 2015;163:1204-1213.

9. Scott OM, Hyde SA, Goddard C, Dubowitz V. Quantitation of muscle function in children: a prospective study in Duchenne muscular dystrophy. Muscle Nerve 1982;5: 291-301.

10. de C Pereira CA, Lemle A, Algranti E, et al. I Consenso Brasileiro Sobre Espirometria. J Pneumol 1996;22:105-164. 
11. Castelli EC, Paz MA, Souza AS, Ramalho J, Mendes-Junior CT. Hla-mapper: an application to optimize the mapping of HLA sequences produced by massively parallel sequencing procedures. Hum Immunol 2018;79:678-684.

12. Lima THA, Souza AS, Porto IOP, et al. HLA-A promoter, coding, and 3'UTR sequences in a Brazilian cohort, and their evolutionary aspects. HLA 2019;93:65-79.

13. Allen RC, Zoghbi HY, Moseley IAB, Rosenblatt HM. Methylation of Hpall and Hhal sites near the polymorphic CAG repeat in the human androgen-receptor gene correlates with X chromosome inactivation. Am J Hum Genet 1992;51:1229-1239.

14. Bittel DC, Theodoro MF, Kibiryeva N, Fischer W, Talebizadeh Z, Butler MG. Comparison of $\mathrm{X}$-chromosome inactivation patterns in multiple tissues from human females. J Med Genet 2008;45:309-313.

15. Heckmatt JZ, Sewry CA, Hodes D, Dubowitz V. Congenital centronuclear (myotubular) myopathy: a clinical, pathological and genetic study in eight children. Brain 1985;108:941-964.

16. Grogan PM, Tanner SM, Ørstavik KH, et al. Myopathy with skeletal asymmetry and hemidiaphragm elevation is caused by myotubularin mutations. Neurology 2005;64: 1638-1640.

17. Drouet A, Ollagnon-Roman E, Streichenberger N, et al. Expression hémicorporelle d'une myopathie myotubulaire liée à l'X (XLMTM) chez deux des trois femmes conductrices d'une même famille sans cas masculin. Rev Neurol (Paris) 2008;164: $169-176$.

18. Hammans SR, Robinson DO, Moutou C, et al. A clinical and genetic study of a manifesting heterozygote with X-linked myotubular myopathy. Neuromuscul Disord 2000;10:133-137.

19. Sutton IJ, Winer JB, Norman AN, Liechti-Gallati S, MacDonald F. Limb girdle and facial weakness in female carriers of $\mathrm{x}$-linked myotubular myopathy mutations. Neurology 2001;57:900-902.

20. Pénisson-Besnier I, Biancalana V, Reynier P, Cossée M, Dubas F. Diagnosis of myotubular myopathy in the oldest known manifesting female carrier: a clinical and genetic study. Neuromuscul Disord 2007;17:180-185.

21. Hedberg C, Lindberg C, Máthé G, Moslemi AR, Oldfors A. Myopathy in a woman and her daughter associated with a novel splice site MTM1 mutation. Neuromuscul Disord 2012;22:244-251.

22. Herman GE, Kopacz K, Zhao W, Mills PL, Metzenberg A, Das S. Characterization of mutations in fifty North American patients with X-linked myotubular myopathy. Hum Mutat 2002;19:114-121.

23. De Gouyon BM, Zhao W, Laporte J, Mandel JL, Metzenberg A, Herman GE. Characterization of mutations in the myotubularin gene in twenty six patients with X-linked myotubular myopathy. Hum Mol Genet 1997;6:1499-1504.

24. Laporte J, Guiraud-Chaumeil C, Vincent MC, et al. Mutations in the MTM1 gene implicated in X-linked myotubular myopathy. Hum Mol Genet 1997;6: 1505-1511.

25. Hedberg ML, Goh G, Chiosea SI, et al. Genetic landscape of metastatic and recurrent head and neck squamous cell carcinoma. J Clin Invest 2016;126:169-180.
26. Tanner SM, Schneider V, Thomas NST, Clarke A, Lazarou L, Liechti-Gallati S. Characterization of 34 novel and six known MTM1 gene mutations in 47 unrelated X-linked myotubular myopathy patients. Neuromuscul Disord 1999;9:41-49.

27. Hou L, Chen M, Ng J, Hurley CK. Conserved KIR allele-level haplotypes are altered by microvariation in individuals with European ancestry. Genes Immun 2012;13:47.

28. Dahl N, Hu LJ, Chery M, et al. Myotubular myopathy in a girl with a deletion at Xq27q28 and unbalanced X inactivation assigns the MTM1 gene to a $600 \mathrm{~kb}$ region. Am J Hum Genet 1995;56:1108-1115.

29. Nussbaum RL, McInnes RR, Willard HF. Chapter 16-Risk assessment and genetic counseling. In: Nussbaum RL, McInnes RR, Willard HF, editors. Thompson \& Thompson Genetics in Medicine, 8th ed. Elsevier, Philadelphia; 2015:333-348.

30. Moser H, Emery EH, Hospital WG. The manifesting carrier in Duchenne muscular dystrophy. Clin Genet 1974;5:271-284.

31. Viggiano E, Ergoli M, Picillo E, Politano L. Determining the role of skewed $\mathrm{X}$-chromosome inactivation in developing muscle symptoms in carriers of Duchenne muscular dystrophy. Hum Genet 2016;135:685-698.

32. Sumita DR, Vainzof M, Campiotto S, et al. Absence of correlation between skewed X inactivation in blood and serum creatine-kinase levels in Duchenne/Becker female carriers. Am J Med Genet 1998;80:356-361.

33. Azofeifa J, Voit T, Hübner C, Cremer M. X-chromosome methylation in manifesting and healthy carriers of dystrophinopathies: concordance of activation ratios among first degree female relatives and skewed inactivation as cause of the affected phenotypes. Hum Genet 1995;96:167-176.

34. Fialkow PJ. Primordial cell pool size and lineage relationships of five human cell types. Ann Hum Genet 1973;37:39-48.

35. Dobyns WB. The pattern of inheritance of $X$-linked traits is not dominant or recessive, just X-linked. Acta Paediatr Int J Paediatr 2006;95:11-15.

36. Zatz M, Pavanello RCM, Lazar M, et al. Milder course in Duchenne patients with nonsense mutations and no muscle dystrophin. Neuromuscul Disord 2014;24: 986-989.

37. Van Den Bergen JC, Hiller M, Böhringer S, et al. Validation of genetic modifiers for Duchenne muscular dystrophy: a multicentre study assessing SPP1 and LTBP4 variants. J Neurol Neurosurg Psychiatry 2015;86:1060-1065.

38. Hsu KC, Chida S, Geraghty DE, Dupont B. The killer cell immunoglobulin-like receptor (KIR) genomic region: gene-order, haplotypes and allelic polymorphism. Immunol Rev 2002;190:40-52.

39. Martin MP, Gao X, Lee JH, et al. Epistatic interaction between KIR3DS1 and HLA-B delays the progression to AIDS. Nat Genet 2002;31:429-434.

40. Lanier LL, Chang C, Azuma M, Ruitenberg JJ, Hemperly JJ, Phillips JH. Molecular and functional analysis of human natural killer cell-associated neural cell adhesion molecule (N-CAM/CD56). J Immunol 1991;146:4421-4426.

41. Illa I, Leon-Monzon M, Dalakas MC. Regenerating and denervated human muscle fibers and satellite cells express neural cell adhesion molecule recognized by monoclonal antibodies to natural killer cells. Ann Neurol 1992;31:46-52. 


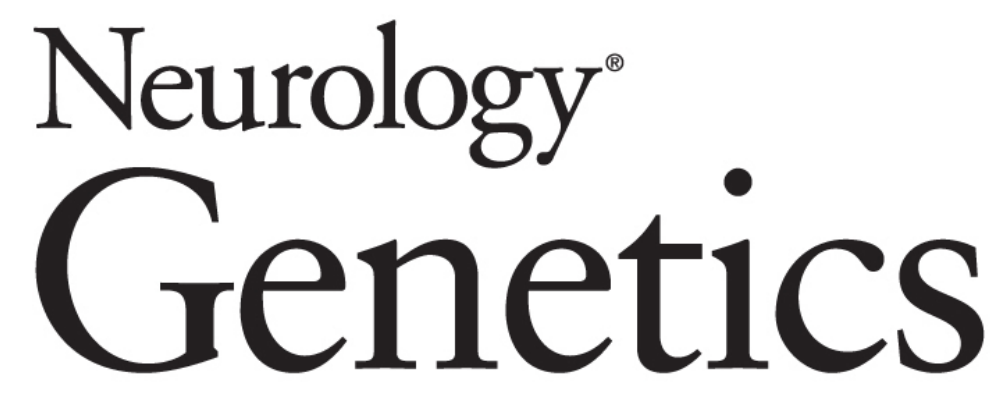

\section{Manifesting carriers of X-linked myotubular myopathy: Genetic modifiers modulating the phenotype}

Lucas Santos Souza, Camila Freitas Almeida, Guilherme Lopes Yamamoto, et al. Neurol Genet 2020;6;

DOI 10.1212/NXG.0000000000000513

This information is current as of September 4, 2020

\section{Updated Information \&} Services

References

Citations

Subspecialty Collections

Permissions \& Licensing

Reprints including high resolution figures, can be found at: http://ng.neurology.org/content/6/5/e513.full.html

This article cites 40 articles, 3 of which you can access for free at: http://ng.neurology.org/content/6/5/e513.full.html\#\#ref-list-1

This article has been cited by 4 HighWire-hosted articles: http://ng.neurology.org/content/6/5/e513.full.html\#\#otherarticles

This article, along with others on similar topics, appears in the following collection(s):

All Neuromuscular Disease

http://ng.neurology.org//cgi/collection/all_neuromuscular_disease Muscle disease

http://ng.neurology.org//cgi/collection/muscle_disease

Information about reproducing this article in parts (figures,tables) or in its entirety can be found online at:

http://ng.neurology.org/misc/about.xhtml\#permissions

Information about ordering reprints can be found online: http://ng.neurology.org/misc/addir.xhtml\#reprintsus

Neurol Genet is an official journal of the American Academy of Neurology. Published since April 2015, it is an open-access, online-only, continuous publication journal. Copyright Copyright $\odot 2020$ The Author(s). Published by Wolters Kluwer Health, Inc. on behalf of the American Academy of Neurology.. All rights reserved. Online ISSN: 2376-7839.

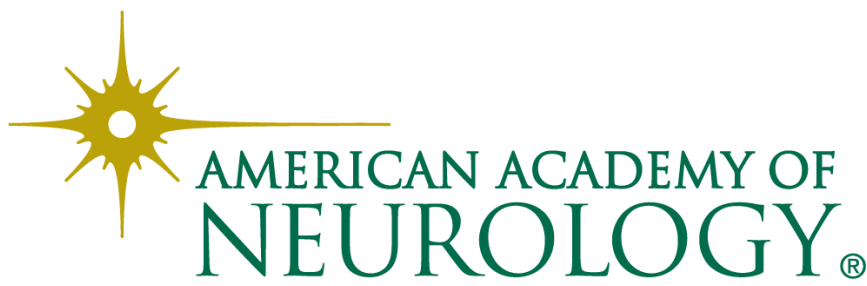

